DOI 10.18551/rjoas.2019-11.36

\title{
CONVERSION OF PADDY FIELDS AND IMPACT ON FARMERS' INCOME IN ACEH BESAR DISTRICT OF INDONESIA: A CASE STUDY OF DARUL IMARAH SUBDISTRICT
}

\author{
Zais Ichwal ${ }^{*}$ \\ Postgraduate Program, Syiah Kuala University, Banda Aceh, Indonesia \\ Romano, Nugroho Agus \\ Faculty of Agriculture, Syiah Kuala University, Banda Aceh, Indonesia \\ *E-mail: ichwalzais@gmail.com
}

\begin{abstract}
Post-Tsunami in Aceh province the issue of agricultural land to non-agricultural land continues to increase. In line with the increasing population and high economic growth led to increased land demand. Residents choose a safe area that is an area far from the sea and close to the urban area as a place to live so that there is agricultural land turned function into a settlement land. he purpose of this research is to determine the rate of change in the land use of rice fields in Darul Imarah subdistrict in 2007 and 2016 and its impact on farmers income. The rate of land function was analyzed by the equality of land function and the impact of land conversion was analyzed descriptively. The results showed that the trend over the function of rice paddy field in District Darul Imarah has fluctuation from the year 20072016. The rate of paddy field function is 18.21 percent or 0.18 percent per year with a pattern of changing paddy fields to a residential area of 167.51 ha. While the impact of land conversion is the result of changes in the average total revenue of farmers before and after the conversion of land is experiencing the addition of Rp. 1.093.939. The average income before the conversion of agricultural land amounted to Rp. 1.263.636 and the average income after the conversion of agricultural land amounted to Rp. 2.357.575.
\end{abstract}

\section{KEY WORDS}

Land conversion, farmer income, Darul Imarah, areas, public relations.

Land conversion is a consequence of increased activity and population and other development processes. Change of function of agricultural land, especially paddy fields, will affect paddy production which is the staple food of Indonesian people. Kamaruzzaman (2009) states that since the earthquake and tsunami disaster in Aceh, development in the city of Banda Aceh has shifted increasingly towards the southern part of the city which is a suburban of Banda Aceh. Aceh Besar district has several districts bordering the province of Banda Aceh districts such Lhong, Peukan Bada, Darul Imarah, Ingin Jaya, Krueng Barona Jaya, and Baitussalam.

Darul Imarah subdistrict is one of the subdistricts experiencing changes in agricultural land use to non-agriculture and increasing population after the Tsunami. Based on data recorded at the Central Statistics Agency, the population growth rate in Darul Imarah subdistrict is the highest population in Aceh Besar Regency. This causes agricultural land, especially rice fields, to be increasingly narrow because land needs are increasing to meet the needs of an unlimited population. Rapid population growth and the increasing demands of the community's need for land, often resulting in conflicts of interest in land use as well as a mismatch between land use and designation plans (Khadiyanto, 2005).

Narrowing of agricultural land will have an impact on the economic condition of farmers. Farmers who were originally farmers are now landowners and they are slowly changing their position to become traders, construction workers and unemployed, so farmers have difficulty in meeting the needs of farm families. This illustrates that there has been a change in livelihoods from the agricultural to non-agricultural sectors. As stated by Afandi (2011) that the impact of the conversion of paddy fields causes farmers to lose agricultural 
output as much as the area of land converted, lost employment opportunities in farming, as well as income opportunities and economic activities related to farming.

The phenomenon of the conversion of agricultural land is the impact of the transformation of economic and demographic structures which ultimately drives changes in land resources from agriculture to non-agriculture (Supriyadi, 2004). The agricultural sector still has many major problems that must be resolved, one of which is the problem of the conversion of agricultural land into non-agricultural land. This solution must be sought for a solution because seeing the impact arising from the conversion of this land can be detrimental to farmers.

\section{MATERIALS AND METHODS OF RESEARCH}

This research was conducted in Darul Imarah subdistrict, Aceh Besar Regency. The scope of this study is limited to the rate of land use change and the impact of land use change on farmers income due to the characteristics of farmers which include age, education, experience and land area.

The population of this research is farmers who convert their rice fields into nonagricultural land or buildings. The sampling method of this study uses the Snowball method in which the informant is chosen through determining the source sample first and then recommending which informant is suitable for interview. The informants interviewed are those who are considered to know the surrounding conditions such as village heads, farmers and local communities. The latest information is based on the saturation of information, which is when no variation of the data provided by the informants is found, the search for further informants and additional data is stopped.

Sources of data used in this study are primary and secondary data. Primary data collection techniques are done by recording, interviewing and observing directly to the location of the study in the form of a farmer interview. Whereas secondary data in the form of Administrative Maps and Land Use Maps were obtained from BAPPEDA Aceh Besar, Aceh Besar District Data in numbers and Darul Imarah District Data in figures obtained from the Central Statistics Agency (BPS). The tools used in this study were computers with Microsoft Office Exel 2007, Geographic Information System (GIS), Statistical Program and Service Solution (SPSS) 20.0 and Global Positioning System (GPS).

\section{RESULTS AND DISCUSSION}

Characteristics of respondents in the study area were obtained based on interviews conducted with fifty-seven farmers respondents who carried out the conversion of paddy fields. These general characteristics consist of the age of the farmer, level of education, farming experience and land area can be seen in Table 1 below.

Table 1 - Characteristics of Respondents

\begin{tabular}{|c|c|}
\hline No Characteristics of Respondents & Value \\
\hline Average Age (Year) & 45 \\
\hline Average Education (Year) & 12 \\
\hline Average Experience (Year) & 16 \\
\hline Average Land (Meter) & 3.246 \\
\hline
\end{tabular}

Source: Primary Data (2017).

Based on Table 1 above, it can be seen that the majority of respondents who conducted land use change in the Darul Imarah subdistrict were 45 years old farmer. This shows that the average age of farmers who do land conversion is still productive. Productive age plus an average experience of 16 years farmers should be able to learn more to develop their abilities and expertise in farming. Farming experience shows how long farmers have been carrying out agricultural activities, so farmers can work efficiently and effectively and can increase farm production. 
The level of education determines how people think in decision making. Higher education will make it easier for farmers to manage and develop farming. The average education level of respondents in the study site was 12 years, this shows that the farmers who converted their paddy fields to senior high school level.

The total area of land owned by farmers carrying out land use in Darul Imarah subdistrict is on an average area of $3.246 \mathrm{~m} 2$. This shows that paddy fields are decreasing so that if the government does not control it is feared that all paddy fields will turn into buildings.

The conversion of the function of agricultural land in the Darul Imarah sub-district is in the form of rice fields and most of it has been converted into housing. The conversion of paddy fields to farmers is basically voluntary or forced. Voluntary conversion of rice paddies is a process of land conversion carried out by farmers based on the wishes of the farmers without any influence from others. Whereas forced is the process of land conversion due to coercion from other parties, namely neighbors, agents or housing developers. The land conversion process can be seen in Table 2 below.

Table 2 - Process of Land Use Change

\begin{tabular}{|c|c|c|}
\hline Process & Respondent & Percentage (\%) \\
\hline Voluntarily & 17 & 30 \\
\hline Forced & 40 & 70 \\
\hline Total & 57 & 100 \\
\hline
\end{tabular}

Source: Primary Data (2017).

Based on Table 2 above, it can be seen that the process of land conversion is carried out by most farmers because they have to. Actually, farmers do not want to sell their land because agriculture is the main source of livelihood. However, due to the persuasion of the agents so that farmers sell their land to the developer / housing developer with a profit sharing system that is the farmer as the land owner does not incur any costs in the construction process but the house has been built for two with the housing developer so that farmers also get a part of the house, besides the absence of irrigation channels also resulted in farmers forced to choose to change the function of their rice fields. However, there are also farmers who voluntarily process agricultural land conversion at 30 percent. This is due to the needs of farmers or farm families who need high costs such as children's education, child marriage, paying debts and venture capital.

Land use in the Darul Imarah subdistrict has a diverse distribution. However, in this study only five types of land use were analyzed, namely paddy fields, settlements, shrubs, dry land agriculture and forests. The changes in land use in 2007 and 2016 in Darul Imarah subdistrict can be seen in Table 3 below.

Table 3 - Rate of Change in Land Use of Darul Imarah Subdistrict in 2007 and 2016

\begin{tabular}{|c|c|c|c|c|}
\hline \multirow{2}{*}{ Land Use } & \multicolumn{3}{|c|}{ Year Change } & Laju Perubahan \\
\cline { 2 - 4 } & 2007 & 2016 & $(\mathrm{Ha})$ & $(\%)$ \\
\hline Sawah & 825,64 & 675,33 & $-150,31$ & $-18,21$ \\
\hline Permukiman & 985,88 & 1184,07 & 198,19 & 0,20 \\
\hline Semak Belukar & 82,98 & 35,56 & $-47,42$ & $-0,57$ \\
\hline Pertanian Lahan Kering & 346,46 & 208,91 & $-137,55$ & $-0,40$ \\
\hline Hutan & 199,83 & 336,92 & 137,09 & 0,69 \\
\hline
\end{tabular}

Source: Secondary Data (2017).

Table 3 above explains that the most extensive type of land use is residential land, namely 985.88 ha in 2007 to $1,184.07$ ha in 2016 with a rate of change of $0.20 \%$, spatially the land use in Darul Imarah sub-district can be seen in Figure 1 and 2. The smallest land use is the bush which is 82.98 ha in 2007 which experienced an area of 47.42 ha with a rate of change of $0.57 \%$. However, the type of land use that has decreased the highest rate of land area is paddy land by 150.31 ha or $18.21 \%$. Therefore, serious handling from the 
government is needed so that the conversion of rice fields can be controlled. The patterns of land use change in Darul Imarah District can be seen in Table 4 below.

Table 4 - Patterns of Change in Land Use of Darul Imarah Subdistrict 2007-2016

\begin{tabular}{|c|c|c|c|c|c|c|}
\hline \multirow{2}{*}{ Land Use 2007 (Ha) } & \multicolumn{7}{|c|}{ Land Use 2016 (Ha) } \\
\cline { 2 - 7 } & Sawah & Permukiman & $\begin{array}{c}\text { Semak } \\
\text { Belukar }\end{array}$ & $\begin{array}{c}\text { Pertanian Lahan } \\
\text { Kering }\end{array}$ & Hutan & Total \\
\hline Sawah & 657,01 & 167,51 & 0,00 & 23,98 & 0,00 & 848,50 \\
\hline Permukiman & 0,00 & 901,75 & 0,00 & 0,00 & 0,00 & 901,75 \\
\hline Semak Belukar & 0,00 & 0,00 & 0,00 & 0,00 & 199,83 & 199,83 \\
\hline Pertanian Lahan Kering & 32,13 & 106,20 & 60,91 & 184,93 & 23,58 & 407,75 \\
\hline Hutan & 0,00 & 1,88 & 72,04 & 0,00 & 208,88 & 282,81 \\
\hline Total & 689,13 & $1.177,35$ & 132,95 & 208,91 & 432,29 & $2.640,63$ \\
\hline
\end{tabular}

Source: Secondary Data (2017).

Table 4 above states that the pattern of land use change in the Darul Imarah subdistrict in 2007 and 2016 was dominated by paddy fields at 848.50 ha. Paddy fields are converted into settlements of 167.51 ha, spatially the land use patterns in Darul Imarah subdistrict can be seen in Figure 3. This shows that the shrinkage of paddy fields in Darul Imarah sub-district occurred because of the strategic location, growing population growth increasing every year so that it requires land for housing construction and public facilities. Housing development also had an impact on other paddy fields that were turned into dry agricultural land by 23.98 ha. This is because the paddy fields they own are already close to housing developments. With the construction of housing around agricultural land, especially rice fields, causing obstruction of irrigation channels. This causes the paddy fields to become unproductive which in turn will harm farmers because of crop failure.

Changes in livelihoods will affect the income earned, farmers receive income not only from the results of farming, but there is also income from non-farming businesses such as trading, the results of rental homes, and other businesses. Farmer income is basically divided into two types, namely farm income and income outside the farming sector. Farming income is income received from the agricultural sector, while non-farming income is income derived from outside the agricultural sector. Income obtained from farmers before and after converting land can be seen in the following Table 5.

Table 5 - Average Farmers Income Before and After Land Conversion

\begin{tabular}{|c|c|c|c|c|c|}
\hline \multirow{2}{*}{ Farmers Income } & \multicolumn{2}{|c|}{ Farm } & \multicolumn{2}{c|}{ Non-Farm } & Average Farmers Income \\
\cline { 2 - 5 } & Rupiah & $\%$ & Rupiah & $\%$ & Rupiah \\
\hline Before Land Conversion & 760.606 & 60,00 & 503.030 & 40,00 & 1.263 .636 \\
\hline After Land Conversion & 493.939 & 21,00 & 1.924 .242 & 79,00 & 2.418 .181 \\
\hline Change & -266.667 & & 1.421 .212 & & 1.093 .939 \\
\hline
\end{tabular}

Source: Data Primary (2017).

Based on Table 5 above, it can be seen that the total income of farmers in Darul Imarah District from farming and non-farming since before and after land conversion has changed from Rp. 1.263.636 to Rp. 2.418.181. This shows the addition of the average total income obtained by respondents after land conversion of Rp.1.093.939. The increase in income derived from non-farming is higher than the decrease in income derived from farming. The change in average non-farm income is Rp.1.421.212 and the change in farming is Rp. -266.667. However, based on the value of the Gross Regional Domestic Product (GRDP) based on the prevailing price, the income in the agricultural business field is Rp.2.624.842. This shows that the income of respondents in the District of Darul Imarah is still below the GRDP value of Aceh Besar district. 


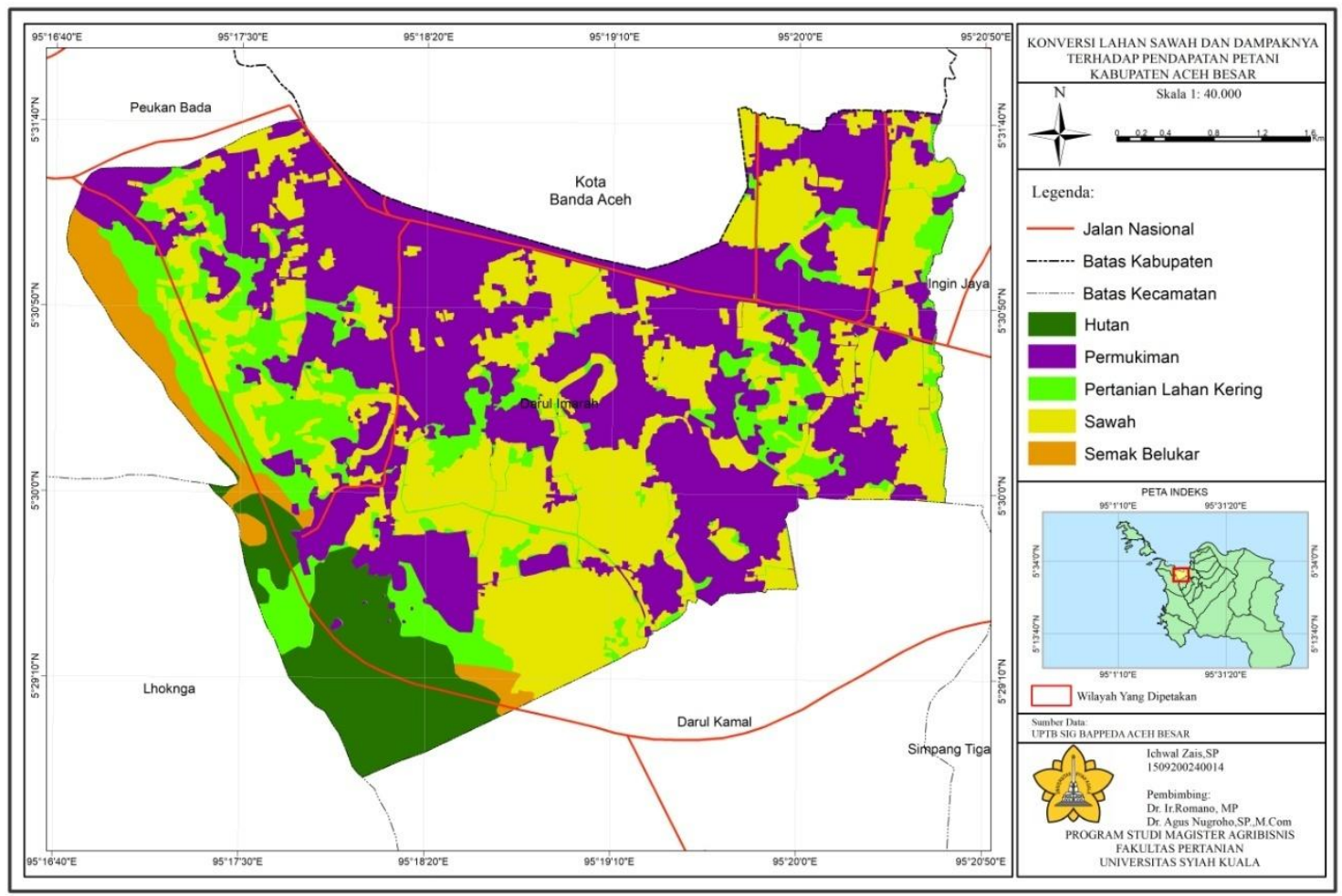

Figure 1 - Map of Land Use in 2007

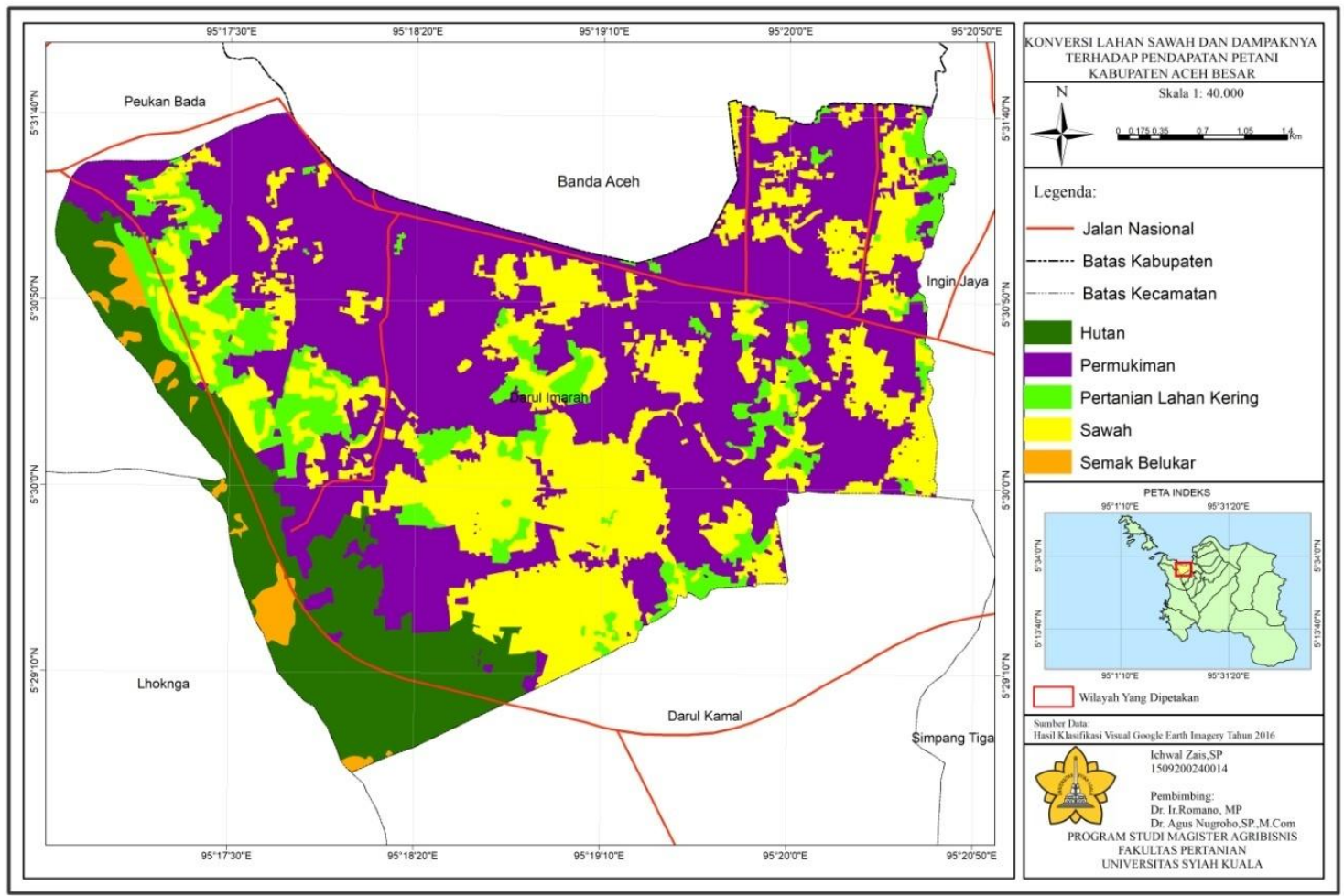

Figure 2 - Map of Land Use in 2016 


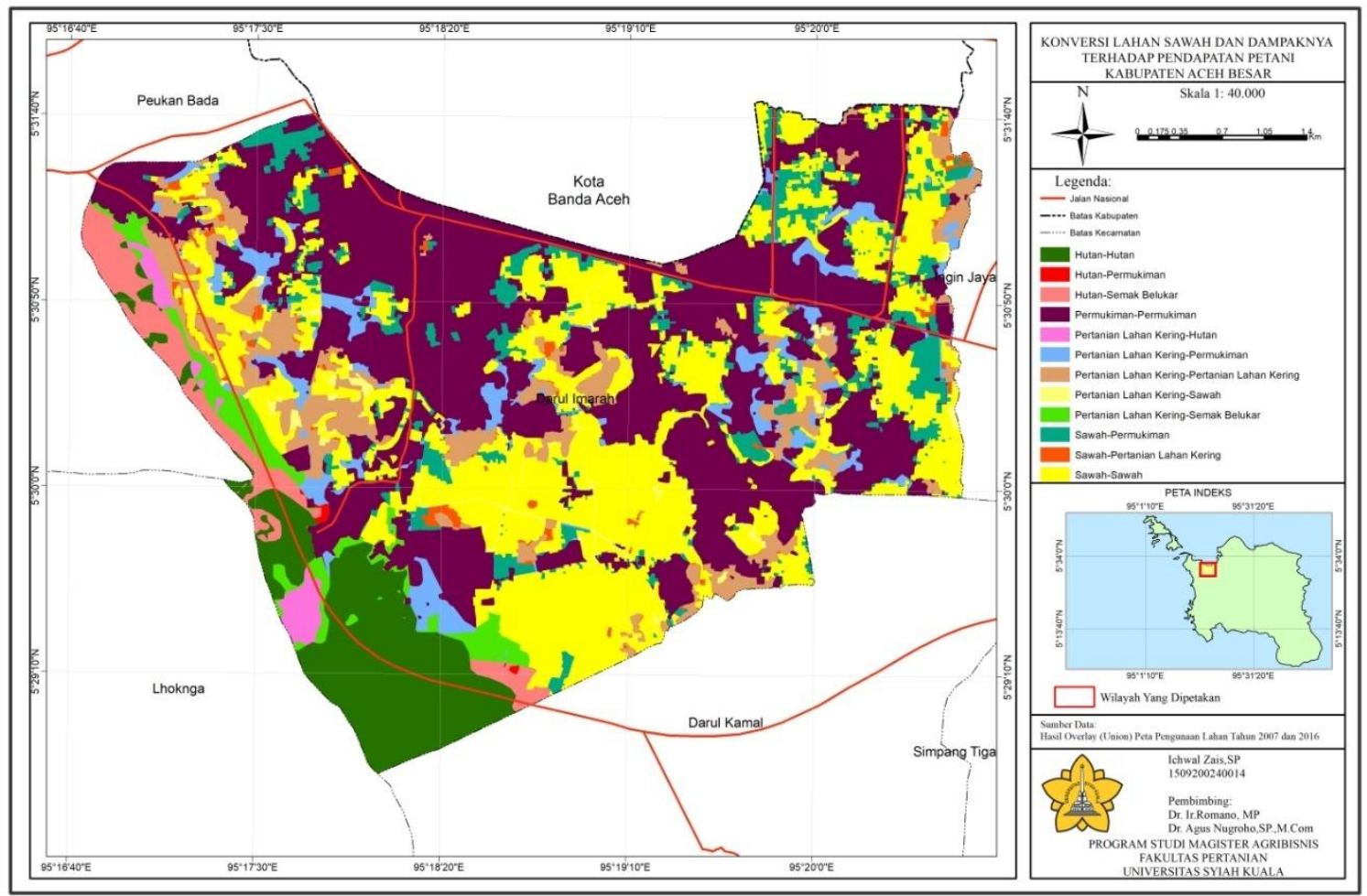

Figure 3 - Map of land use change from 2007-2016

\section{CONCLUSION}

Based on the results of research and discussion that has been done, it can be concluded that the rate of land conversion in Darul Imarah sub-district from 2007-2016 was 18,21 percent with an average rate of land conversion of 0,18 percent per year. The biggest land use change is paddy land into residential land which is equal to 167,51 ha. Land conversion causes changes in the average income of farmers before and after doing land conversion which has increased by Rp.1.093.939. The addition is obtained from non-farm income which shows that there has been a shift in livelihood from agricultural to nonagricultural businesses.

\section{REFERENCES}

1. Afandi, Muhamad Nur. 2011. Policy Analysis of Agricultural Land Transfer Function Against Food Security in West Java. Journal of Administrative Sciences. Vol. VIII No.2 August 2011.

2. Badan Pusat Statistik. 2016. Regency of Aceh Besar in Numbers. BPS, Aceh Besar.

3. Kamaruzzaman.2009. Direction of Spatial Use in the Development of Sub-Urban Areas of Banda Aceh City in the Aftermath of the Tsunami (Case Study of Ulee Kareng, Lueng Bata, and Banda Raya Districts). Thesis. Postgraduate of Bogor Agricultural University, Bogor.

4. Khadiyanto, P. 2005. Spatial Planning Based on Land Suitability. Diponegoro University, Semarang.

5. Supriyadi A.2004. Land Change Function Policy and Land Conversion Process (Case study: Pasuruan Regency, East Java). IPB. Bogor. 